\title{
Sartre: Passagem da Psicologia à Fenomenologia*
}

\author{
Luiz Damon Santos Moutinho**
}

Resumo: Este texto investiga a passagem sartriana à filosofia primeira. O mérito maior da fenomenologia - a superação da querela entre realismo e idealismo - será comprometido pelo pensamento ulterior de Husserl, caracterizado como "idealista". Recusando o conceito de noema irreal, Sartre procurará retomar os "verdadeiros princípios" da fenomenologia, reinaugurando o discurso da filosofia primeira.

Palavras-chave: Sartre - psicologia - fenomenologia - consciência - intencionalidade - imagem - noema

Após os primeiros ensaios de psicologia, escritos durante os anos 30, Sartre, já em 1943, aparece com um "ensaio de ontologia fenomenológica", obra que, apenas por esse subtítulo, muda o tom em relação às anteriores. Isso resulta, para Spiegelberg por exemplo, numa sequiência surpreendente cuja conexão não parece clara; Sartre, diz ele, "oferece poucos indíci 
explícitos para a conexão em sua obra na sua surpreendente seqüência" (Spiegelberg 14, p. 471) .

Para que compreendamos essa passagem, talvez valha a pena começar lembrando a distinção entre psíquico e transcendental, estabelecida desde 1934, no Essai sur la Transcendance de l'Ego. Essa distinção sofreu algumas mudanças, à medida que novos conceitos surgiam; mas ela mesma, enquanto tal, permaneceu, reafirmando sempre, de um lado, o psíquico, objeto da psicologia, e de outro, o transcendental, dbjeto da fenomenologia. Não cabe aqui apontar as transformações que essa distinção sofreu, mas apenas lembrar o papel fundante que, para Sartre, a fenomenologia sempre teve: "De uma maneira geral o que lhe interessa (à Psicologia) é o homem em situação. Enquanto tal, ela é (...) subordinada à fenomenologia, pois um estudo verdadeiramente positivo do homem em situação deveria elucidar de início as noções de homem, mundo, ser-no-mundo e situação" (Sartre 8, p. 17) . A psicologia não pode "ser um começo", pela simples razão de que os fatos psíquicos também não o são: "Eles são, em sua estrutura essencial, reaçães do homem contra o mundo; supõem portanto o homem e o mundo e não podem tomar seu sentido verdadeiro a não ser que se tenham de início elucidado essas duas noçães" (id., ibidem, p. 13) . Essa elucidação, por sua vez, cabe à fenomenologia: "Se queremos fundar uma psicologia, precisaremos ir além do psíquico, além da situação do homem no mundo, até a fonte do homem, do mundo e do psíquico: a consciência transcendental e constitutiva que alcançamos pela 'redução fenomenológica'" (id., ibidem) .

Contudo, embora conceda à fenomenologia esse papel de prima philosophia, nosso filósofo não sai do terreno da psicologia. Aí pelos anos 30 desenvolve apenas, como um bom discípulo de Husserl, uma "psicologia fenomenológica da imaginação" e um "esboço de uma teoria fenomenológica das emoções". Assim, por exemplo, em A Imaginação, após mostrar as insuficiências da psicologia introspectiva e reclamar uma psicologia eidética, ele diz: "É a ele (Husserl) que vamos pedir, agora, para guiar nossos primeiros passos nesta ciência difícil" (idem 12, p. 95) . Reclamando a influência husserliana, Sartre dedica-se portanto àquela área do saber cujo sentido depende de outra, desenvolvida por Husserl.
Essa imagem de "bom discípulo" deve contudo ser nuançada. Afinal, já em Essai, Sartre pretende fazer reparos ao Eu transcendental de Ideen, ainda que para estabelecer a consciência não-egológica das Investigaçães; em A Imaginação, tem dificuldade em aceitar o noema irreal, por não ver como distingui-lo da imagem. Entretanto, essas objeçães não representam ainda uma dificuldade a ponto de se tomar necessário reescrever a "ciência da consciência pura transcendental" (Sartre 12, p. 97), que é como lhe aparece a fenomenologia. É verdade que na Conclusão de $L^{\prime}$ Imaginaire passa ao plano do transcendental, quando se coloca a questão de saber se imaginar é uma especificação contingente ou essencial da consciência; mas tratase aí de resolver um problema não devidamente enfrentado por Husserl. Ora, o que vai ocorrer mais tarde, e causar espécie a Spiegelberg, é que em L'Être et le Néant é precisamente toda a fenomenologia que está em questão, é toda ela que é reescrita. Sartre se coloca de vez no plano da fenomenologia pura, desenvolvendo ele mesmo aquela "ciência da consciência pura transcendental"! E de fato: em Esquisse, citamos acima, aparece como tarefa da fenomenologia a elucidação das "noções de homem, mundo, ser-nomundo e situação", exatamente a elucidação de que L'Être et le Néant procura se desincumbir: "Qual é a relação sintética que chamamos o ser-nomundo? (...) Que devem ser o homem e o mundo para que a relação seja possível entre eles?" (idem 10, p. 38).

Assim, temos, de um lado, as primeiras obras como exercícios de psicologia fenomenológica; a essa altura, apesar de algumas observações à fenomenologia de Husserl, esta parece contudo fornecer os instrumentos básicos ao desenvolvimento da psicologia. Ela é já aquela "ciência da consciência pura transcendental". De outro lado, temos L'Être et le Néant se propondo responder precisamente àquelas questões fundantes da Psicologia e que são objeto mesmo da "ciência da consciência"(1) . Ora, o que aconteceu nesse percurso? O que se passou com a fenomenologia de Husserl (e, certamente, também a de Heidegger), que se tornou necessário reescrevêla? Por que, além disso, tomou ela a forma de uma ontologia? 
Em A Imaginação, a fenomenologia de Husserl parece fornecer os instrumentos necessários para a elaboração e desenvolvimento das ciências positivas. Entretanto, apenas parece. Porque não é sem considerandos que Sartre apresenta esse "grande acontecimento da filosofia" (Sartre 12, p. 97) ; já aí, ele detecta alguns problemas que dizem respeito, ao final das contas, à noção de objeto intencional.

Num primeiro momento, ele procura estabelecer a posição fundante da fenomenologia, e estabelecê-la em condições diversas daquelas do Essai, de modo que se torne possível a constituição de uma psicologia fenomenológica ainda ignorada em 1934. Com Husserl, temos finalmente um método - uma "experiência privilegiada" - que nos põe "imediatamente em contato com a lei" (id., ibidem, p. 95), isto é, com a essência, base daquela psicologia. Entretanto, "Husserl não se contenta em nos fornecer um método" (id., ibidem, p. 99); ele lança ainda as "bases" para uma nova psicologia. Essas "bases" são, de início, o conceito de intencionalidade e a recusa do conceito de "representação", sua conseqüência mais óbvia para Sartre: "O psicologismo, partindo da fómula ambígua 'o mundo é nossa representação', faz com que se desvaneça a árvore que percebo em uma miríade de sensações, de impressões coloridas, tácteis, témicas etc., que são 'representações" (id., ibidem) . Que se lembre aqui da "filosofia alimentar", "digestiva", e o Espírito-Aranha que atrai as coisas para sua teia, cobrindo-as de uma baba branca e recuzindo-as à sua própria substância (idem 11, p. 29) . Husserl, entretanto, estabelecendo "uma distinção radical entre a consciência e aquilo de que se tem consciência", "começa por colocar a árvore fora de nós" (idem 12, p. 99) .

A essa altura, a hylé não oferece problemas: ela é sem dúvida "conteúdo de consciência", mas não "o objeto da consciência": "Certamente, ele (Husserl) não nega a existência de dados visuais ou táteis, que fazem parte da consciência como elementos subjetivos imanentes. Mas eles não são o objeto: a consciência não se dirige para eles; através deles visa à coisa exte- rior" (Sartre 12, p. 99). Aqui, um pequeno parêntese: trata-se exatamente de coisa exterior: mesmo quando, e isso desde o Essai, o objeto intencional aparece como "unidade ideal" de uma "infinidade de aspectos", esse objeto, paradoxalmente, não é senão a coisa exterior, o objeto espaço-temporal (idem 9, p. 33) ${ }^{(2)}$ ! Assim, a hylé convive aqui com a coisa em "carne e osso": espécie de "quase vermelho", sobre ela "se aplica a intenção que se transcende e procura atingir o vermelho que está fora dela" (ídem 12, p. 100) . De todo modo, o mérito da intencionalidade é assegurado, uma vez que a hylé não representa o inerte que o associacionismo humiano introduz na consciência. Ainda que "impressão subjetiva", ela não é uma "impressão enfraquecida" (id., ibidem, p. 87) : a hylé não guarda traço de opacidade porque ela não é representação, porque não "duplica"; ela é apenas uma "matéria subjetiva" que "perfila" a cor, a superfície etc. Ainda que "conteúdo de consciência", ela é o ultrapassado em favor do objeto, a intenção se dirige para fora, para a árvore "fora de nós", exterior, espaço-temporal.

Ora, esse mesmo esquema vale também para a imagem. Como em uma percepção, distinguir-se-á "uma intenção imaginante e uma hylé que a intenção vem 'animar'" (id., ibidem, p. 100) . Quanto à imagem, ela "deixa de ser um conteúdo psíquico; ela não se acha na consciência a título de elemento constituinte" (id., ibidem) . O dbjeto, destacado da hylé, situa-se "fora da consciência" também aqui. Conforme citação de Ideen, "o centauro em si mesmo não é, naturalmente, nada de psíquico, ele não existe na alma nem na consciência, nem em parte alguma; não existe absolutamente, é em seu todo invenção" (id., ibidem) (3) . Com isso, a imagem deixa de ser "conteúdo inerte" e torna-se ato: "Consciência una e sintética em relação com um objeto transcendente". A imagem de Pedro não é mais um "Pedro em formato reduzido", mas uma "forma organizada de consciência que se relaciona, à sua maneira, a Pedro" (id., ibidem). Forma organizada de mesmo tipo daquelas que se dirigem a "quadros, desenhos, fotos", ditas imagens "externas": "Se a imagem torna-se uma certa maneira de animar um conteúdo hilético, poder-se-á muito bem assimilar a apreensão de um quadro como imagem à apreensão intencional de um conteúdo 'psíquico'" (id., ibidem, p. 101), como é o caso da imagem que formo de meu amigo Pedro. 
E certamente: a imagem sendo ato, forma de consciência, em nada impede essa aproximação, para além da diversidade das "matérias" (Sartre 13, p. 42). A "família da imagem" se alarga, se diversifica, como "espécies de um mesmo gênero" (id., ibidem, p. 45) . É assim que a apreensão de uma águaforte de Dürer é também imagem; na verdade, posso apreender essa águaforte de duas maneiras diferentes: pela percepção normal, onde o correlato é a coisa gravrura, ou pela contemplação estética, onde nos dirigimos "para as realidades representadas 'em imagem', mais exatamente, para as realidades 'imagificadas', o cavaleiro de carne e osso etc." (idem 12, p. 101) ${ }^{(4)}$. Nesse caso, a hyléé "indubitavelmente a mesma", na aparição estética e na pura e simples percepção. A diferença se acha antes na "estrutura intencional": a "tese" recebeu, na aparição estética, uma "modificação de neutralidade". De onde a conclusão de que a matéria, isto é, a hylé é insuficiente para distinguir imagem e percepção; é preciso pensar antes no "modo de animação da matéria" (id., ibidem) .

Essa distinção, contudo, diz respeito à percepção e às imagens extemas; é necessário abordar ainda a imagem mental, e abordá-la perguntando evidentemente por sua hylé. Será esta a mesma que a da percepção? Quando formo a imagem de Pedro, a hylé é a mesma de quando o percebo? Parece que dessa vez apenas a "estrutura intencional" será insuficiente, pois se fossem as matérias idênticas seria preciso convir que a imagem mental apareceria aqui como sensação renascente, de base sensível, numa palavra, coisificada. Segundo Sartre, há motivos para desconfiar de que é assim para Husserl; por exemplo, quando ele toma a rememoração como implicando a reiteração, "ainda que em uma consciência modificada, de todos os atos perceptivos originais": a imagem-lembrança aparece portanto como uma "consciência perceptiva modificada, isto é, afetada por um coeficiente de passado"; desse modo, a lembrança de um teatro iluminado outrora percebido implica a "reprodução da percepção do teatro iluminado" (id., ibidem, p. 102; grifos nossos) . Ou, ainda, quando concede à imagem a função de "preencher" saberes vazios: "Se penso em uma cotovia, posso fazê-lo no vazio, isto é, produzir apenas uma intenção significante fixada sobre a palavra 'cotovia' . Mas, para preencher essa consciência vazia e transformá-la em consciência intuitiva, é indiferente que eu forme uma imagem de cotovia ou olhe uma cotovia de carne e osso" (Sartre 12, p. 102) . A imagem aqui parece possuir uma "matéria impressional concreta", ser um cheio, "como a percepção".

Se isso é admitido, o problema se agravará ainda mais quando for operada a redução fenomenológica: com ela, surgirão dificuldades que tornarão a distinção entre imagem mental e percepção ainda mais difícil. As dificuldades se colocam na medida em que o noema aparece como irreal. Sartre faz igualar esse irreal, no plano fenomenológico, com o que, já antes, sabia do centauro imaginado, também irreal: "Agora a coisa árvore foi posta entre parênteses, não a conhecemos mais senão como o noema de nossa percepção atual; e, como tal, este noema é um irreal, assim como o centaurd" (id., ibidem, p. 103; grifos nossos). Centauro que "também não é nada", que "também não existe em lugar nenhum" (id., ibidem) ${ }^{(5)}$. Ora, ocorre que, antes da redução, "encontrávamos nesse nada mesmo um meio para distinguir a ficção da percepção" (id., ibidem) : a árvore em flor estava aí, coisa espaço-temporal; já o centauro "não estava em parte alguma, nem em mim, nem fora de mim" (id., ibidem). Claro que o problema se coloca tendo por pressuposto que a "ambivalência hilética", antes observada, se repete aqui (antes, ela significava o fato de que gravuras, fotos etc., podem ser percebidas como coisas ou contempladas esteticamente). Supondo agora que a imagem mental é sensação renascente, e que portanto agora sua hylé é a mesma da percepção, nosso problema se agrava com a redução fenomenológica na medida em que ambos, árvore e centauro, aparecem agora como irreais; já não temos a árvore em flor que podíamos estreitar, tocar etc. E Sartre entende que assim parece ser para Husserl, quando este fala, por exemplo, em aparição ora caracterizada como "realidade em carne e osso", ora como ficção, no interior do plano fenomenológico: é como se se tratasse de intenções diferentes animando uma mesma matéria, isto é, como se bastasse a intenção para diferir "carne e osso" de "ficção".

Parece assim que o próprio Husserl é vítima da ilusão da "sensação renascente". Husserl que, no primeiro momento, parecia ter-se afastadb dessa concepção (que Sartre denomina "ilusão de imanência": nosso hábito de pensar a consciência em termos de espaço). Afinal, foi Husserl mesmo quem distinguiu imagem extema e percepção pelas intenções, e não pelas matérias, estabelecendo assim uma distinção "intrínseca" que nada tinha que ver com 
a intensidade humiana. Husserl, contudo, parece se mostrar vítima daquela ilusão na medida em que repete essa mesma concepção, válida para as imagens externas, para o caso da imagem mental. Parece agora que a distinção não pode estar apenas na "estrutura intencional", ou, por outra, parece que a identificação das matérias não pode ser feita, a menos que eu acredite poder animar uma hylé "como percepção ou imagem a meu belprazer": "Desde que se trate de uma imagem mental, cada qual pode verificar que é impossível animar sua hylé para fazer dela a matéria de uma percepsão" (Sartre 12, p. 104). Será necessário afi mar, portanto, para além da diferença das intenções, a diferença das matérias, e isso aparentemente contra Husserl, apontando positivamente qual a matéria da imagem mental. Observe o leitor que o problema da imagem aparece em Sartre condicionando integralmente sua colocação do problema do noema, de modo que a solução daquele forçará a retomar esse último, levando à solução distinta daquela de Husserl.

III

A hylé da imagem mental será caracterizada em L' Imaginaire. É a essa obra que a conclusão de A Imaginação remete e, já um pouco antes, ao terminar o capítulo sobre Husserl, e enumerando os problemas que deverão ser tratados na obra seguinte, Sartre destaca entre eles o problema da hylé: "Enfim, e principalmente, será preciso estudar a hylé própria da imagem mental" (id., ibidem, p. 105). Já sabemos que a "família da imagem" envolve desde a psíquica até as imagens externas, tais como retratos, caricaturas, imitações, desenhos esquemáticos, manchas em muros etc. Em quaisquer dos casos, a consciência imaginante será sempre "consciência de um objeto em imagem, e não consciência de uma imagem" (idem 13, pp. 171-172) . Se quero me voltar para o ato imagem, preciso refletir: "A imagem como imagem não é descritível senão por um ato de segundo grau pelo qual o olhar se volta do objeto para se dirigir à maneira pela qual esse objeto é dado" (Sartre 13, p. 15) . Essa reflexão não é outra que a reflexão eidética, no plano da psicologia.

Assim, é preciso, de início, pôr-se de acordo quanto a isso: uma representação mental, uma fotografia e uma caricatura que têm por objeto meu amigo Pedro são maneiras diferentes de visar ao mesmo objeto, que não é "nem a representação, nem a foto, nem a caricatura: é meu amigo Pedro" (id., ibidem, p. 41). A hylé - termo que não aparece em L'Imaginaire, sendo traduzido sempre por "matéria" - é, nos dois últimos casos, um objeto físico, que "pode ser percebido por si mesmo" (id., ibidem, p. 42) : a foto e a caricatura. Essa hylé, quando "animada" por uma intenção imaginante, torna-se um analogon; assim, "eu me sirvo de uma certa matéria que age como analogon, como um equivalente da percepção" (id., ibidem); ela não deve ser qualquer, mas "deve apresentar alguma analogia com o objeto em questão" (id., ibidem, p. 45). O analogon é portanto a matéria mesma, mas animada e, nessa medida, representante do abjeto.

Ora, todo o capítulo "A Família da Imagem" não é senão uma descrição reflexiva desse analogon para o caso daquelas imagens extemas; a descrição, que começa com o retrato e termina com a imagem hipnagógica ${ }^{(6)}$, segue o critério em que o analogon é progressivamente diminuído nas suas qualidades representativas, fazendo crescer com isso o trabalho da consciência, via movimento, saber e afetividade: "À medida que a matéria da consciência imaginante se afasta da matéria da percepção, à medida que ela se penetra mais de saber, sua semelhança com o objeto da imagem se atenua. Um fenômeno novo aparece: o fenômeno de equivalência. (...) O movimento será hipostasiado como equivalente da forma, a luminosidade como equivalente da cor" (id., ibidem, p. 107) . Com o "empobrecimento" da matéria, o saber cresce em importância e "a intenção ganha em espontaneidade" (id., ibidem, p. 108). Assim, num crescendo, quando se chegar à imagem mental, por sua matéria não ter exterioridade, ela deverá aparecer como espontaneidade plena. Mas isso também implicará em que, quando se chegar à imagem mental, a própria reflexão não possa mais ser operada - dada a não exterioridade da matéria. E de fato: naqueles primeiros casos, "quando a consciência propriamente imaginante se esvanecia, restava um resíduo sensível 
que se podia descrever: era a tela pintada ou a mancha do muro" (Sartre 13, p. 111). Dessa vez, contudo, a reflexão aniquila, junto à consciência imaginante, a matéria que the servia de analogon: "Não permanece resíduo que se possa descrever, encontramo-nos em face de uma outra consciência sintética que nada tem em comum com a primeira" (id., ibidem, p. 112). Por conta disso, será preciso "abandonar o terreno seguro da descrição fenomenológica e voltar à psicologia experimental" (id., ibidem), ou, se se quiser, será preciso abandonar o terreno do "certo" e passar ao do "provável".

Ora, com isso nosso problema parece se complicar, pois, afinal, conforme sabemos, a hylé da percepção aparece sempre acessível à reflexão: "Cada 'Erlebnis' é feita de tal forma, que existe uma possibilidade, em princípio, de dirigir o olhar para ela e para os seus componentes reais ou, numa direção oposta, para o noema", diz Sartre citando Husserl (idem 12, p. 103) (7). Já a hylé da imagem mental, ao contrário, por ser puramente psíquica, não resiste à reflexão. Perdemos, assim, qualquer possibilidade de uma resposta positiva acerca de uma possível "ambivalência hilética" entre percepção e imagem mental.

Mas será de fato assim? Pela razão mesma dessa impossível comparação não encontramos uma resposta bastante que ateste a inexistência daquela ambivalência hilética? Parece que sim, e para isso basta que nos lembremos de que, se a hylé da imagem mental é "conteúdo psíquico", é verdade também que ela é transcendente, e isso é assegurado ainda no terreno do "certo"; essa transcendência é afirmada dada a "necessidade para a matéria da imagem mental de ser já constituída em objeto para a consciência" (idem 13, p. 110) . Ora, é precisamente essa transcendência que inexiste na hylé da percepção. Trata-se, nesse caso, de elementos subjetivos imanentes: são "dados visuais ou tácteis que fazem parte da consciência como elementos subjetivos imanentes", mas que "não são o objeto" (idem 12, p. 99) . Essa imanência da matéria da percepção, por seu lado, é o avesso do caráter passivo da percepção, por oposição ao caráter espontâneo da imagem mental, na qual a matéria é inteiramente constituída, produto de nossa livre espontaneidade: "Uma consciência perceptiva se aparece como passividade. Ao contrário, uma consciência imaginante se dá a si mesma como consciência imaginante, isto é, como uma espontaneidade que produz e conserva o ob- jeto em imagem" (Sartre 13, p. 35). A espontaneidade vai aqui ao ponto de constituir uma matéria psíquica transcendente que funciona como analogon. Ora, isso não é razão bastante para se afimar uma dessemelhança entre as cuas matérias?

Não, de fato não. Basta que consideremos o caso anterior, a gravura de Dürer. A hylé da percepção é imanente, e isso atesta bastante a passividade da percepção. Entretanto, se tomamos essa mesma gravura como imagem, na qual a hylé se mantém, já não podemos mais falar de imanência. De fato, a espontaneidade mesma da imagem, na medida em que anula a passividade da percepção, anula igualmente a hylé enquanto imanência: toda matéria de toda imagem é transcendência. É mesmo porque, quando se refere à reflexão a propósito da imagem externa, Sartre fala não de "resíduos impressionais", mas de um "resíduo sensível" que não é senão a própria tela pintada ou mancha do muro: também aqui o conteúdo transcendente se aniquila com a reflexão, como ocorre no caso da imagem mental; daí por que precisamos "refazer certos movimentos", deixar novamente "agir sobre nós as linhas e as cores" (id., ibidem, p. 111), numa palavra, "reconstituir" o analogon! A partir daqui é forçoso concluir que imanência num caso e transcendência no outro não são garantias de dessemelhança entre as matérias.

De qualquer forma, ainda que a natureza da hylé da imagem mental seja mera hipótese, pode-se assegurar com certeza não ser ela de base sensível. Em L' Imaginaire é a vez de objetar a Husserl, que aparece agora como vítima de fato, não apenas suspeito (como ocorria em A Imaginação), da "ilusão de imanência". Sartre cita novamente as Investigações e retoma a tese do "preenchimento" (Erfüillung): "Se penso 'andorinha', por exemplo, posso ter de início apenas uma palavra e uma significação vazia no espírito. Se a imagem aparece, faz-se uma nova síntese e a significação vazia tomase consciência plena de andorinha" (id., ibidem, p. 118). Essa tese, segundo Sartre, é "chocante". A objeção a ela é feita pela lembrança de que a imagem é ela mesma uma consciência; ao invés de preenchimento de significação, trata-se antes de "significação degradada, descida ao plano da intuição" (id., ibidem, p. 64). Assim, na imitação, por exemplo, se os elementos propriamente intuitivos são pobres, eles serão substituídos pela afetividade, de modo a realizar o objeto em imagem (id., ibidem, p. 63) : há aqui "mu- 
dança de natureza", não preenchimento (Sartre 13, p. 64) . E é precisamente isso o que ocorre com a imagem mental, de modo que Sartre aponta aqui como analogon as impressões cinestésicas, mais amplamente os movimentos, o dbjeto afetivo (id., ibidem, p. 161), a palavra (id., ibidem, p. 169) etc., nunca "dados visuais ou tácteis". Assim, por exemplo, quando fecho os olhos e traço um "8" com o indicador: uma forma será visualizada irrealmente sobre a impressão cinestésica real (id., ibidem, p. 158) .

Ora, a que nos levou tudo isso? Sem dúvida, levou-nos bem além daquela "aparência de resposta" (idem 12, p. 104) que A Imaginação levantou, e que consistia apenas em apontar uma síntese passiva para a percepção e uma síntese ativa para a imagem, explicação que, de resto, Sartre subscrevia "inteiramente". E continuou a fazê-lo em L'Imaginaire; apenas dessa vez procurou mostrar em que consiste de fato a matéria da imagem mental. Entretanto, é lícito perguntar: isso responde integralmente aos problemas levantados em A Imaginação? Basta simplesmente mostrar a hylé desprovida de caráter sensível para que aqueles problemas tenham sido resolvidos?

Aparentemente, sim. Havia de início a observação de que Husserl parecia supor uma "ambivalência hilética" entre percepção e imagem mental; por conta dessa ambivalência, colocava-se a dificuldade adicional em se distinguir uma coisa da outra no plano fenomenológico. Assim, desde que se mostre a dessemelhança das matérias, tudo de fato parece resolvido. Entretanto, devemos nos lembrar de que se a ambivalência hilética apareceu como um problema - ela supõe ser a imagem mental uma sensação renascente -, esse problema se agravou com a redução fenomenológica, e se agravou porque um elemento novo foi introduzido: o noema irreal. Afinal, "antes da redução", sabíamos, malgrado aquela ambivalência, distinguir uma coisa da outra: agora, "uma vez feita a redução", já não sei "distinguir o centauro que imagino da árvore em flor que percebo" (id., ibidem, p. 103) . Esse elemento novo parece constituir-se aqui num problema a mais: agora a própria árvore, coisa do mundo, aparece como irreal: eis aqui a outra face do problema. Se a distinção das matérias resolve a questão da hylé da imagem mental, ela deixa intacto o problema do noema da percepção no interior do plano fenomenológico, pois ele é tornado irreal como o centauro que imagino. Ou, por outra: a solução até aqui diz respeito à diferença entre imagem e percepção na atitude natural; não resolve a questão no plano fenomenológico, pois, mostradas as matérias dessemelhantes, o noema persiste como irreal, tal como o centauro. Evidentemente, esse problema se coloca "uma vez feita a redução". Talvez consigamos uma boa pista para aclarar a nossa questão se começarmos seguindo a trilha da redução, a maneira pela qual ela aparece na obra de Sartre.

IV

(A) No Essai, a redução só pode ser entendida à luz da distinção prévia estabelecida entre dois tipos de reflexão, distinção que, commatizes diversos, será retomada em L'Être et le Néant: a reflexão pura e a reflexão impura. A primeira é aquela que se atém exclusivamente aos dados da imanência, enquanto a última, operando uma "passagem ao infinito", constitui um sentido transcendente para a imanência (por exemplo, o "ódio" para um vivido de repulsão). Dessa maneira é constituído o Ego, que se dá como permanente, para além de minha consciência atual. A recução fenomenológica, por seu lado, aparecerá como um "ato reflexivo puro" que entrega a consciência a si mesma "como espontaneidade não-pessoal" (Sartre 9, p. 73) . E, na medida em que deve ser apreensão da verdadeira espontaneidade, isto é, da consciência pura sem Ego, a redução fenomenológica exige ainda "ser realizada sem nenhuma motivação anterior" (id., ibidem) . É a motivação psicológica, por exemplo, na origem do método cartesiano ("empresa de um Eu"), que o faz encontrar "um Eu em seu horizonte" (id., ibidem) . O cogito é aqui impuro.

A redução, por seu lado, será possível porque, apesar de a consciência constituir o Ego "como uma falsa representação de si mesma" (id., ibidem, p. 82) e com o objetivo "de mascarar à consciência sua própria espontaneidade" (id., ibidem, p. 81), esse esforço não será "jamais completamente recompensado": "Basta um ato simples de reflexão para que a espontaneidade consciente se arranque bruscamente do Eu e se dê como 
independente" (Sartre 9, p. 84) . Evidentemente, trata-se de uma reflexão não motivada, razão pela qual a epoché aparece não como "um milagre", não como "um método intelectual, um procedimento sábio", mas antes como "uma angústia que se impõe a nós e que não podemos evitar", "um evento puro de origem transcendental e um acidente sempre possível em nossa vida cotidiana" (id., ibidem, p. 84). Assim, ao contrário do que acontece em Husserl, não operamos a redução, ela nos acontece, ela se impãe a nós, tal como a náusea. Já não é mais um método, um procedimento, mas um acidente na nossa vida: é a espontaneidade que, por acidente, livrando-se das amarras do Eu, se nos impõe decisivamente.

Mas não curará muito essa visada do Essai. Já na obra seguinte, em $A$ Imaginação, desaparece por completo esse caráter acidental da redução. Ela é agora um "método", um "procedimento" que permite uma "intuição de essências" (idem 12, p. 97) . Da mesma forma em L' Imaginaire. A rechção fenomenológica aparecerá como "método" e adequado apenas ao campo da fenomenologia, por oposição à redução eidética, aplicada no terreno da psicologia. E de fato: na primeira parte da obra, quando o assunto era psicologia, foi operada a redução eidética. Já na Conclusão, quando pela primeira vez Sartre passa ao plano da fenomenologia, quando se volta para a consciência transcendental, a questão do método já não aparece tão simples. Começa reafirmando que a redução fenomenológica nos coloca "em presença da consciência transcendental", permitindo-nos "fixar por conceitos o resultado de nossa intuição eidética da essência 'consciência'" (idem 13, p. 343) . Mas isso apenas no primeiro momento! Porque, logo a seguir, ele afima: "Essa questão (a de saber se a função de imaginar é essencial ou contingente) deveria poder se regular pela simples inspeção reflexiva da essência 'consciência' e é assim que tentaríamos regulá-la de fato, se não nos dirigíssemos a um público ainda pouco acostumado aos métodos fenomenológicos. Mas, como a idéia de intuição eidética repugna ainda a muitos leitores franceses, usaremos de um viés, isto é, de um método um pouco mais complexo" (id., ibidem, pp. 344-345). Observe o leitor que esse é o primeiro momento em que Sartre é posto diante da necessidade de operar a redução fenomenológica - e simplesmente não a opera.
(B) Conforme escreve Sartre em seus diários, os "últimos capítulos" de L'Imaginaire não foram escritos sob "inspiração" de Husserl. Segundo ele, na verdade toda a obra é escrita "contra" Husserl, "mas tanto quanto um discípulo pode escrever contra seu mestre" (Sartre 7, p. 226). Parece-nos que o "contra" se deve aqui à recusa do caráter sensível da hylé da imagem mental, ou, por outra, à recusa da tese do preenchimento. De qualquer modo, mesmo que "contra" Husserl, ainda sob sua "inspiração". Já os "últimos capítulos" representam um afastamento de Husserl, não ainda, é certo, a ruptura mais profunda acontecida em L' $L^{\prime}$ tre et le Néant ${ }^{(8)}$, mas um afastamento. Parece-nos que "os últimos capítulos", não indicados por Sartre, são na verdade a quarta parte e a Conclusão da obra, o que representa cerca de um terço de L'Imaginaire. Não porque apenas aí apareça o nome de Heidegger ${ }^{(9)}$, mas porque só aí é introduzido o conceito ser-no-mundo.

Que esse conceito implica? Lembremos que o problema da Conclusão é saber se "a função de imaginar é uma especificação contingente e metafísica da essência 'consciência' ou (se) ao contrário deve ela ser descrita como uma estrutura constitutiva dessa essência" (idem 13, p. 344). Problema que deveria ser abordado pela redução fenomenológica, mas que não o será devido à ignorância francesa dos "métodos fenomenológicos". Assim, a questão deve tomar outra forma, nos moldes do "método regressivo" da análise crítica: "Que deve ser uma consciência para poder imaginar?" (id., ibidem, p. 345) . Os resultados aí obtidos serão "comparados" àqueles que nos dá a "intuição cartesiana realizada pelo cogito" (id., ibidem) . Esse é o "viés" pelo qual escapamos da redução, redução cuja possibilidade, tenhamos isso presente, convive aqui com o conceito ser-no-mundo. Sigamos esse método, pois através dele será introduzido o conceito ser-no-mundo, conceito cuja implicação nos forçará a recolocar a nossa questão anterior - a questão do noema irreal.

Para introduzir a regressão, Sartre estabelece de início o caráter específico da imagem, pelo qual ela se distingue da lembrança ou do ser visado no vazio (pelas intenções vazias - por exemplo, os arabescos do tapete escondidos pela cadeira) . E entre todas as características estabelecidas no primeiro capítulo da primeira parte ${ }^{(10)}$, válidas para a imagem externa ou men- 
tal, Sartre retoma a terceira delas: "A consciência imaginante põe seu abjeto como um nada". Minha imagem de Pedro "é uma certa maneira de não tocá-lo, de não vê-lo, uma maneira que ele tem de não estar a tal distância (...) Neste sentido, pode-se dizer que a imagem envolve um certo nada. (...) Tão viva, tão tocante, tão forte que seja uma imagem, ela dá seu objeto como não sendo" (Sartre 13, pp. 34-35) .

Assim, retomada no processo regressivo, essa será a primeira condição "para que uma consciência possa imaginar: é preciso que ela tenha a possibilidade de pôr uma tese de irrealidade" (id., ibidem, p. 351), ou seja, é preciso que ela tenha a possibilidade de pôr o nada. Pois, ao me representar Pedro, "eu apreendo nada (rien), isto é, eu ponho o nada (rien)" (id., ibidem, p. 349) . Dessa forma, pode-se afimar que a questão adquire aqui um novo escopo: regressão a propósito da imagem, de fato; mas apenas enquanto é por ela que a consciência põe o nada, ou enquanto é por ela que o ato negativo se realiza ${ }^{(11)}$. E aqui, tal como em Bergson, o Nada é sempre relativo; supondo um "há prévio" (Prado Jr. 6, p. 58), o Nada-de-algumacoisa é posterior logicamente. Dessa vez, ele aparece relativo à "totalidade do real": "Pôr uma imagem é constituir um objeto à margem da totalidade do real, é ter o real à distância, dele se libertar, em uma palavra, negá-lo" (Sartre 13, p. 352) . Assim, Charles VIII, dbjeto irreal, deve aparecer sempre "fora de alcance por relação à realidade" (id., ibidem) .

Ora, aqui mesmo outra condição se revela: para que o ato negativo se realize, será necessária a apreensão da "totalidade do real", ou antes, será necessário que a consciência "possa pôr o mundo em sua totalidade sintética". Entretanto, essa condição ultrapassa de longe a mera condição da imagem, na qual apreender a totalidade do real é constituí-lo como mundo, o que, repetindo Heidegger, Sartre chama "nadificação": "Pôr o mundo como mundo ou 'nadificá-lo' é uma só e mesma coisa" (id., ibidem, p. 354). E essa apreensão do real como mundo, por sua vez, só é possível se a consciência está situada, se ela é-no-mundo, termo último da regressão: é preciso que a consciência esteja "em situação no mundo", que ela "seja-nomundo", para que haja "constituição e nadificação do mundo" (id., ibidem, p. 357). Assim, a regressão, partindo da imagem, chegou ao ser-no-mundo como sua condição; o nada, para ser posto, exige a apreensão da totalidade do real, isto é, do mundo como conjunto sintético, ou ainda: o Nada exige a apreensão do Todo, e esse, por sua vez (que se dá no ato de nadificação), exige a situação. Do nada ao mundo e daí ao ser-no-mundo: eis as fases da regressão analítica.

Mas o método, conforme vimos, não pára por aí; ele exige ainda a "comparação" com o que nos oferece o cogito ${ }^{(12)}$. Vejamos o que acerca disso nos diz Sartre: "Essa consciência livre, com efeito, auja natureza é ser consciência de alguma coisa, mas que, por isso mesmo, se constitui a si mesma em face do real e que o ultrapassa a cada instante porque ela só pode ser 'sendo-no-mundo', isto é, vivendo sua relação ao real como situação, que é senão simplesmente a consciência tal como se revela a si mesma no cogito?" (Sartre 13, p. 357). De um único golpe, o cogito legitima o ser-nomundo e seu conceito correlato, o de nadificação; o cogito reclama aqui o mundo. E de fato: "A condição mesma do cogito não é de início a dúvida, isto é, ao mesmo tempo a constituição do real como mundo e sua nadificação (...) ?" (id., ibidem) . Exigência um tanto singular: não será ela mesma - "a consciência só pode ser 'sendo-no-mundo'" - a razão mais profunda, para além da ignorância francesa, da dificuldade com a recução, recução que precisamente põe o mundo "fora de jogo", "entre parênteses"? Por ora, deixemos essa questão em suspenso; lembremos apenas que a nadificação implica ainda "ultrapassamento": a "consciência (...) se constitui a si mesma em face do real e (...) o ultrapassa a cada instante porque ela só pode ser 'sendbno-mundo', isto é, vivendo sua relação ao real como situação" (id., ibidem) . Ou, por outra: "Todo existente, desde que é posto, é por isso mesmo ultrapassado" (id., ibidem, p. 359); na verdade, nadificar o mundb é constituí-lo por ultrapassagem. Ora, mas para que é ultrapassado o existente?

Segundo intenpretação sartriana de Heidegger, do texto ao qual remete essa discussão, Que É Metafísica?, o para-quê em Heidegger é o nada, tido por Sartre como "extra-mundano" (idem 10, p. 55) ${ }^{(13)}$. Essa é a interpretação presente em L' Être et le Néant, mas temos razões para crer que é já aquela de L'Imaginaire. Não será por outro motivo que o para-quê em Sartre aparecerá em nítida oposição a Heidegger. Essa oposição se constituirá numa clivagem importante no pensamento de Sartre. Pouco importa aqui a justeza da interpretação; importa-nos saber por que o Nada ultra-mundano deve 
ser recusado. E para compreendê-lo talvez devamos recorrer à crítica bergsoniana à idéia de Nada; essa crítica nos ajudará a compreender a objeção de Sartre a Heidegger e o papel do negativo no seu pensamento.

V

(A) A crítica à idéia do Nada em Bergson procurará exatamente mostrar como essa idéia "não corresponde nem a uma experiência pura, nem está implicada em qualquer experiência possível" (Prado Jr. 6, p. 50) . Entretanto, ainda que não haja experiência do Nada, "é incontestável que se fala do Nada" (id., ibidem). E esse falar "postula o Nada como horizonte do Ser". o problema, contudo, diz respeito não ao que é dito, mas ao que é "efetivamente pensado", de onde a necessidade, apesar de tudo, de se procurar saber "se o vocabulário do negativo nasce de uma experiência do próprio negativo" (id., ibidem) . Mas, de fato, a experiência do Nada se revelará impossível; a imaginação, que por sucessão de eliminações, pretendeu chegar a ele, se verá "aprisionada no interior da Presença" (id., ibidam, p. 51) . Essa impossibilidade, contudo, diz respeito, ao Nada absoluto, pois, por meio do exame da experiência da imaginação, um "Nada parcial" (id., ibidem) apareceu: "A imagem propriamente dita de uma supressão de tudo não é jamais formulada pelo pensamento. O esforço pelo qual tendemos a criar essa imagem consegue simplesmente nos fazer oscilar entre a visão de uma realidade exterior e a de uma realidade interna. Nesse vaivém de nosso espírito entre o fora e o dentro, há um ponto, situado a igual distância dos dois, em que nos parece que já não percebemos um e que ainda não percebemos o outro: é aí que se forma a imagem do nada" (Bergson 1, p. 731). Aqui, pois, o Nada como "realidade derivada", nada relativo: "Nada-de-mundo ou Nadade-consciência" (Prado Jr. 6, p. 52), "não os dois ao mesmo tempo" (Bergson 1, p. 731).

Não é contudo apenas um nada relativo que aqui se revela: é ainda a posterioridade do nada. Do mesmo modo no que se refere à idéia do Nada quando constituída não pela imaginação, mas por uma atividade conceitual, pois se se pode conceder que não imaginamos o Nada, pode-se ainda pretender que o concebemos, como ocorre com o quiliógono. O resultado é o mesmo: para que haja uma "abolição" de todo objeto da experiência - o Nada não sendo senão a abolição integral - "é necessário que a reiteração da operação conserve o seu passado" (Prado Jr. 6, p. 58), passagem justamente contraditória, pois, na verdade, a supressão de qualquer coisa "corresponde à posição de um outro existente" (id., ibidem, p. 54) : é que não se percebe "jamais a ausência do que quer que seja" (Bergson 1, p. 733), essa ausência só sendo possível "para um ser capaz de lembrança ou de espera" (id., ibidem) . O Nada significa pois um "não-mais" ou um "ainda-não", resultado de negação "essencialmente local", razão pela qual a negação continua aqui "relativa". Se a conservação de negaçães passadas visando ao Nada absoluto é contraditória é porque a negação implica sempre afimação do outro. Assim, o Nada absoluto nada tem que ver com o quiliógono, este sim concebível; ele é antes um impensável, como o "círculo quadrado" (Pradb Jr. 6, p. 56) .

Tampouco a mera representação do negativo, que decreta a inexistência total pura e simplesmente, sem o recurso da abolição, nos leva ao Nada. Na verdade, uma representação tomada como inexistente é a mesma se tomada como existente, já que, conforme "a argumentação kantiana contra a prova ontológica", a existência não é um predicado. Assim, pensar um objeto como inexistente implica de início pensá-lo como objeto, portanto existente, e depois "pensar que uma outra realidade, com a qual ele é incompatível, o suplanta" (id., ibidem, p. 57). Daí por que "há mais, não menos na idéia de um objeto concebido como 'não existente' do que na idéia desse mesmo objeto concebido como 'existente'" (id., ibidem, p. 58). A negação é assim dependente de uma dupla afimação: a afimação anterior do objeto mesmo em questão e a afimação da realidade total que suplanta esse objeto. Também aqui, novamente, se revela a posterioridade do negativo, a necessidade do Ser prévio sobre o qual ele se aplica.

(B) Ora, que tem isso a ver como a recusa sartriana do nada além-mundo de Heidegger? Sabe-se que para Heidegger o Nada não se revela como ob- 
jeto ou como ente, ele se revela ao contrário "juntamente com o ente em sua totalidade" (Heidegger 5, p. 238), se revela com ele de uma única vez. Como em Bergson, não se trata de uma "destruição do ente", de uma negação a partir da qual se atingiria então o Nada; ocorre antes o contrário: o Nada vem a nós, ele "nos visita" na angústia. Se, conforme observa Bento Prado Jr., Heidegger, em Que É Metafísica?, "reproduz o itinerário de Bergson" (Prado Jr. 6, p. 37), é verdade também que aqui ele se separa: o Nada será não uma "ilusão", não uma "miragem", mas a rejeição que remete "ao ente em sua totalidade que desaparece" (Heidegger 5, p. 238) . A essa remissão que rejeita, Heidegger denomina "nadificação" (Nichtung), e, enquanto tal, enquanto remissão que rejeita, o ente aparece "como o absolutamente outro - em face do nada" (id., ibidem, p. 239). Sim, o Nada não é resultado de destruição, de abolição, ou mesmo resultado de uma negação, mas se é assim é porque "o próprio nada nadifica", de onde, na interpretação de Sartre ${ }^{(14)}$, o nada como "vazio indiferenciado ou como alteridade que não se (põe) como alteridade" (Sartre 10, p. 54) . Para Sartre, o nada aparece aqui como "cingindo o ser por toda parte e, por isso mesmo, expulso do ser" (id., ibidem) . É o Nada aqui desempenhando "função transcendental", razão mesma da "impossibilidade" em ser pensado como objeto (Prado Jr. 6, p. 37) : ele aparece como "possibilitação da revelação do ente enquanto tal para o ser-aí humano" (Heidegger 5, p. 239) .

É a esse nada por meio do qual "o mundo recebe seus contornos de mundo" (Sartre 10, p. 54), "alteridade que não se põe como alteridade", que Sartre não dá o seu assentimento. O nada entendido como o para-quê se dá o movimento de ultrapassamento. E é exatamente aqui que surge a referência a Bergson; segundo Sartre, o ultrapassamento se faz sempre, necessariamente, "para alguma coisa", e não para nada. Ou melhor, se faz sempre para o nada de alguma coisa. E a razão parece estar nas análises de Bergson, que, para Sartre, "permanecem válidas: um ensaio para conceber diretamente a morte ou o nada de ser está votado por natureza ao fracasso" (idem 13, p. 359). Por aqui se vê que o Nada absoluto, que a crítica bergsoniana revelou ser "miragem", parece ser aqui identificado ao Nada de Heidegger, que Sartre entende como "extra-mundano", já que o pensa no movimento de ultrapassamento ${ }^{(15)}$. Daí por que esse ultrapassamento se faz para o imaginário (nada do mundo), não para esse "vazio indiferenciado", e para compreendê-lo basta fazer o movimento inverso de L' Imaginaire, não mais regressivo, mas progressivo.

(C) O ser-no-mundo apareceu-nos como a condição última revelada pela regressão analítica. O ser-no-mundo, sempre situado, implica uma permanente "nadificação" do mundo, isto é, uma permanente ultrapassagem do mundo. Ora, essa ultrapassagem, que implica uma posição da totalidade do real (que se revela mundo), só pode ser feita se do lado de lá "algo" se põe por relação a essa totalidade; é precisamente o que ocorre com a imagem, que só se constitui por relação à totalidade do real: "Para que meu amigo Pedro me seja dado como ausente, é preciso que eu tenha sido levado a apreender o mundo como um conjunto tal que Pedro não poderia aí estar atualmente e para mim presente" (Sartre 13, p. 355). Mas para que isso ocorra é preciso ainda que esse "algo" seja um nada - já que se põe por relação à totalidade do real ${ }^{(16)}$. E é essa igualmente, conforme vimos, a característica da imagem: ao me representar Pedro "eu apreendo nada" (id., ibidem, p. 349).

Assim, temos aqui o nada para o qual há o ultrapassamento, o nada do outro lado do mundo, mas que, conforme a crítica bergsoniana, "não pode se dar senão como infra-estrutura de alguma coisa" (id., ibidem, p. 350) . Isto é, um nada de alguma coisa, que se define enquanto tal por relação a alguma coisa - no caso, por relação à totalidade do real -, que se coloca por oposição a essa totalidade. Assim, "o resvalamento do mundo no seio do nada e a emergência da realidade-humana nesse mesmo nada", diz Sartre à maneira de Heidegger, mas opondo-se-lhe, não se dão no nada puro, total, mas "pela posição de alguma coisa que é nada por relação ao mundo e por relação a quê o mundo é nada" (id., ibidem, p. 359) . Eis precisamente como se dá "a constituição do imaginário". É portanto pelo ato mesmo de imaginar que passamos para o outro lado do existente.

Ora, mas isso não implica que "toda percepção do real deva se inverter em imaginário", ou que a imagem seja permanentente posta, tal como em Heidegger a angústia, que revela o nada, não nos acossa permanentemente. Entretanto, "mesmo se nenhuma imagem é produzida nesse instan- 
te, toda apreensão do real como mundo tende por si mesma a se acabar pela procução de objetos irreais" (Sartre 13, p. 356) . E se isso não ocorre é simplesmente porque a produção da imagem exige uma "intenção particular": o mundo leva em si "sua possibilidade de negação, a cada instante e de cada ponto de vista, por uma imagem, ainda que a imagem deva ser constituída por uma intenção particular da consciência" (id., ibidem) . Em Heidegger, trata-se antes de uma "dissimulação" do nada, que se deve ao fato "de nos perdermos, de determinada maneira, absolutamente junto ao ente. Quanto mais nos voltamos para o ente em nossas ocupações, tanto menos nós o deixamos enquanto tal, e tanto mais nos afastamos do nada" (Heidegger 5, p. 239) . Por essa razão mesma, a angústia é "rara". Entretanto, num caso e noutro, a nadificação é "ininterrupta" (id., ibidem) .

Não se trata portanto, se pensamos em Sartre, de que apenas na constituição da imagem o mundo apareça como conjunto sintético; trata-se antes de que "há sempre e a cada instante para (a consciência) uma possibilidade concreta de produzir o irreal" (Sartre 13, p. 358). Inversamente, será apenas pela procução do irreal que a nadificação se descobrirá, tal como em Heidegger o nada se revela apenas na angústia: "Quando o imaginário não é posto de fato, o ultrapassamento e a nadificação do existente estão colados ao existente, o ultrapassamento e a liberdade estão aí, mas não se descobrem, o homem está esmagado no mundo" (id., ibidem, p. 359) .

(D) Para além dessas observações, há contudo uma distinção ainda mais funda, entre Sartre e Heidegger, no que se refere à nadificação. Para Heidegger, o termo mesmo - nadificação - só se coloca uma vez lembrado que o nada não aparece como resultado de uma destruição ou de uma negação; ao contrário, é na medida em que se compreende que sua "essência" é a "remissão que rejeita o ente em totalidade", é nessa medida que se pode falar em "nadificação": o nada não como resultado de uma negação, mas para além de toda negação. É precisamente o significado de "o próprio nada nadifica" (Heidegger 5, p. 238), como se quiséssemos dizer: "O nada se alimenta de si mesmo" (17), se isso não tornasse o nada um ente, rompendo precisamente com o que ocorre na revelação do nada, ou seja, o emudecimento "de qualquer dicção do 'é" " (id., ibidem) . Não há portanto um algo sobre o qual se aplica a nadificação; há, sim, uma "relação nadificadora", um "comportamento nadificador", como a negação, a frustração, a privação, todas fundadas no "nadificar do nada" (Heidegger 5, p. 240) . Elas testemunham a "constante (...) revelação do nada", mas revelação "obscurecida", "que somente a angústia originariamente desvela" (id., ibidem) .

Já em Sartre, as coisas se passam de outro modo. Já não é o "nada que nadifica", mas a consciência, uma vez que não se trata mais de um nada ultra-mundano, "expulso do ser" (Sartre 10, p. 54). Trata-se antes de um nada de ser, que se coloca por relação à totalidade do real; trata-se de um nada que, ao contrário do que ocorre em Heidegger, é alteridade que se põe como alteridade; a imagem é o outro lado do mundo, o para-quê é ultrapassado o existente, é o nada, mas nada por relação ao mundo. Daí por que ele já não exerce "função transcendental" (Prado Jr. 6, p. 37), como o fazia em Heidegger, já não é mais "possibilitação de revelação do ente enquanto tal para o ser-aí humano" (Heidegger 5, p. 239) ; nem poderia exercer esta função, pois se trata de um nada cuja posterioridade é bem definida: nada do mundo. Não que Heidegger afirme a anterioridade do nada, tal como o faz a metafísica clássica criticada por Bergson, mas, ao tomá-lo como "meio infinito" (Sartre 10, p. 58), ignora que o nada só pode dar-se, como Bergson o teria mostrado, "como uma infra-estrutura de alguma coisa" (idem 13, p. 358) . A nadificação torna-se assim não o indicador de uma espécie de subsistência do Nada, mas o modo mesmo pelo qual a consciência apreende o real constituindo-o como mundo. É a consciência, não o nada, que nadifica.

VI

(A) Se é pelas mãos de Heidegger que aparece o conceito ser-no-mundo na obra sartriana, esse conceito já aparece contudo marcado por objeções, conforme uma leitura toda própria de Sartre. Leitura essa que deverá se modificar em vários aspectos já na obra seguinte, L'Être et le Néant, ou 
melhor, já em Drôle de Guerre, obra póstuma escrita cerca de um ano depois da Conclusão de L' Imaginaire. Já aí o conceito ser-no-mundo aparece com novo sentido. E para mostrá-lo é necessário falar aqui, novamente, do nada. Sartre retoma em Drôle de Guerre a tese de L' Imaginaire: a posterioridade do nada. Há uma prioridade do Ser sobre o Nada (Sartre 7, p. 169) ${ }^{(18)}$, diz ele, ou do real sobre o possível (id., ibidem, p. 53). Dessa vez, contudo, o nada já não aparece na figura da imagem, mas, pela primeira vez, a própria consciência aparece como nada. E, também aqui, a questão do nada se esclarece pela análise da negação.

Há dois tipos de negação: uma é aquela que reclama o concurso da consciência ("a mesa não é o tinteiro", "o papel não é poroso") ; esse concurso se reclama na medida em que "não está no ser do papel não ser poroso" (id., ibidem, p. 217). Outra ${ }^{(19)}$, que altera os dados do problema, é aquela em que a própria consciência, "a consciência que nós somos" (id., ibidem, p. 218), está envolvida diretamente, não mais operando uma síntese, mas sendo ela própria a negação; por exemplo, "a consciência não é extensa". Não há aqui "terceiro homem para constatar que duas substâncias inertes, a consciência e a extensão, não têm relação de pertencimento (rapport d'appartenance)" (id., ibidem) . É a própria consciência que deve ser como não sendo a extensão, ela mesma "é seu próprio nada de extensão" (id., ibidem). Segundo Sartre, já não se trata aqui de uma negação que é como uma "categoria" (id., ibidem, p. 217), "ligação categorial e ideal" (idbm 10, p. 223), como no caso precedente, mas de uma negação em que o não tornase "característica existencial" (idem 7, p. 218) ${ }^{(20)}$. Ou, se se quiser, o não já não mais no nível do juízo, mas como modo de ser.

Para que isso seja possível, para que a consciência seja negação da extensão, "é preciso que ela encubra no mais profundo de seu ser uma relação unitária com essa extensão que ela não é" (id., ibidem, p. 219) . Trata-se aqui de uma "ligação tão íntima quanto possível", "unidade sintética" suposta pela negação. Sartre dá um exemplo servindo-se da idéia de contato. Se mantenho uma distância, por infinitesimal que seja, entre dois abjetos, não posso dizer que eles se tocam. Mas tampouco posso fundir um ao outro, pois, ainda que "relação íntima", o contato não é fusão: é necessário garantir a separação entre os objetos. Trata-se de assegurar, ao mesmo tempo que a ausência de distância, uma separação que, contudo, não pode ser pequena, sequer infinitesimal: aqui, nada deve separar os objetos (Sartre 7, p. 222) . É o que ocorre "quando duas curvas são tangentes uma a outra" (idem 10, p. 227).

Retomando o mesmo exemplo de Drôle de Guerre, Sartre dirá: se se permite ver apenas a extensão em que as curvas são tangentes, "seria impossível distingui-las" (id., ibidkm), pois nada as separa. Mbstradas, entretanto, em sua inteireza, "nós as apreendemos novamente como sendo duas sobre toda sua extensão". Isso não ocorre porque realizamos uma "brusca separação", mas porque "os dois movimentos pelos quais traçamos as duas curvas para percebê-las envolvem cada um uma negação como ato constituinte" (id., ibidem). Assim, "uma pura negatividade" separa as chas curvas ali mesmo onde elas se tangenciam, negatividade que é a "contrapartida de uma síntese constituinte" (id., ibidem) .

Ora, é segundo essa forma sintética que Sartre pensa aquela "relação unitária" entre consciência e extensão, relação suposta pela negação: só na base dessa "relação original", a consciência, "sem intervenção contemplativa de um terceiro homem", pode "não ser a extensão" (idem 7, p. 219) . É preciso um tipo de presença da extensão à consciência - que em Drôle de Guerre Sartre chama investissement (id., ibidem, p. 220) - de modo que apenas não sendo a extensão a consciência possa lhe escapar. Essa relação primeira - se tomada a consciência e a "totalidade do em-si" -, pensada com a negação: eis o que Sartre agora denomina "ser-no-mundo"; ela implica "uma aderência imediata e sem distância do mundo ao para-si" (id., ibidem, p. 221), de modo que se constitua aquilo que mais tarde será denominado "identidade negada" (idem 10, p. 227). Trata-se aqui de uma relação de contato do mundo à consciência (idem 7, p. 224), unidade ou síntese que tem uma negatividade como contrapartida, ou, se se quiser, a nadificação.

(B) Ora, já aqui se pode visualizar a distância entre essa idéia de ser-nomundo e aquela de L'Imaginaire. Se antes a nadificação era entendida como um "ato" duplo, que envolvia ao mesmo tempo "o ato de pôr o mundo como totalidade sintética e o ato de 'recuar' com relação ao mundo" (idem 13, p. 354), dessa vez é precisamente o recuo que se torna impensável, e isso 
porque se constituiu agora uma "unidade sintética" (Sartre 7, p. 219) entre consciência e mundo: "O movimento de nadificação do para-si não é um recuo. Se a nadificação se acompanhasse de recuo, ela seria nadificação de nada e recairia no em-si. (...) Ao contrário, a nadificação implica uma aderência imediata e sem distância do mundo ao para-si" (id., ibidem, p. 221), de onde precisamente a idéia de que "a consciência está em contato com o mundo" (id., ibidem, p. 223). Ao invés de recuo, trata-se antes de um "desabamento (effondrement), uma descompressão" (id., ibidem, p. 263) .

Mas não se trata apenas de uma síntese que aparece. É ainda o fato mesmo, até então ausente na obra de Sartre, de a consciência aparecer como o negativo, o que implica novo sentido para o conceito de nadificação. Se em L' Imaginaire era recusada a idéia heideggeriana segundo a qual "o próprio nada nadifica", dessa vez, como que se corrigindo e voltando a Heidegger, novamente o nada nadifica, mas com uma diferença que a passagem por Bergson não eliminou: de fato, o nada por relação ao mundo que era a imagem torna-se aqui a própria consciência; nessa medida, o nada, ou a consciência, nadifica. Mais ainda: o nada recobra a "função transcendental" que havia perdido em L' Imaginaire; ele aparecerá novamente como condição de possibilidade da experiência, como o que torna possível a existência de um objeto para a consciência. Ou, mais precisamente, já não o nada, pois ele é posterior, não ultra-mundano, pois ele é ainda nada de alguma coisa, mas a relação de que ele é membro(21) . Por ora, entretanto, deixemos em suspenso essa questão e voltemos ao problema da redução. Parece-nos que já reunimos aqui alguns elementos que permitem responder à questão que formulávamos atrás.

(C) Dizíamos que a redução não era praticada na Conclusão de L'Imaginaire sob alegação de uma ignorância francesa dos métodos fenomenológicos. Mas será de fato assim, se ali já aparecia o conceito serno-mundo? Não será a idéia mesma de que a consciência está sempre situada, de que ela só pode ser "sendo-no-mundo", a razão mais profunda pela qual a redução não pôde ser praticada? Redução, era o que lembrávamos, que pretende exatamente pôr o mundo "fora de jogo", "entre parênteses"?
Sartre de fato faz coexistir no mesmo texto o conceito ser-no-mundo e a possibilidade da recução, coexistência cuja impossibilidade é apontada por L'Être et le Néant: "O concreto é o homem no mundo com esta união específica do homem ao mundo que Heidegger, por exemplo, chama 'serno-mundo' . Interrogar a 'experiência', como Kant, sobre suas condições de possibilidade, efetuar uma recução fenomenológica, como Husserl, que recuzirá o mundo ao estado de correlativo noemático da consciência, é começar deliberadamente pelo abstrato. Mas não se chegará jamais a restituir o concreto pela soma ou a organização dos elementos que se abstraíram" (Sartre 10, p. 38) . Ora, o que há de específico em L'Imaginaire, que a reoução não aparece ali como abstração, mas como possibilidade (verdade que não efetivada, dada a ignorância francesa... .) ? Parece-nos que isso pode ser compreendido se lembrarmos que o conceito ser-no-mundo aí referido não tem o mesmo sentido que terá logo depois, já em Drôle de Guerre e mesmo em L'Être et le Néant. E de fato: esse conceito exprime agora uma "unidade sintética" entre consciência e mundo desconhecida por L' Imaginaire; tratase de um "investissement" do mundo, uma "ausência de distância" (idem 7, p. 223), que tornam impossível o recuo antes admitido.

Assim, em L' Imaginaire: "O ato de pôr o mundo como totalidade sintética e o ato de 'recuar' com relação ao mundo são um só e mesmo ato. Se podemos usar de uma comparação, é precisamente colocando-se a distância conveniente com relação a seu quadro que o pintor impressionista distinguirá (dégagera) o conjunto 'floresta' ou 'ninféias' da multidão de pequenos toques que ele aplicou sobre a tela" (idem 13, p. 354). Já agora, tomando-se totalidade sintética, é a redução mesma que o ser-no-mundo põe abaixo: é precisamente por separar uma totalidade que ela agora será acusada de "abstração" (idem 10, p. 38) .

Desse modo, parece que aquele nosso primeiro problema surgido em A Imaginação também se encontra resolvido. Lembremo-nos de que a redução implicava ali uma dificuldade à parte, pelo fato mesmo de ela trazer consigo um noema irreal: era "uma vez feita a rechção" que eu não tinha mais como "distinguir o centauro que imagino da árvore em flor que percebo" (idem 12, p. 103) . E esse problema parece se resolver na medida mesma 
em que a própria redução aparece como um erro! Essa solução contudo, evidentemente, não pode nos satisfazer: ela deixa em suspenso a questão da natureza do noema, ou, em termos sartrianos, a questão da natureza do ser. Não é por outra razão, senão para resolver esse problema, que, já na Introcução de L'Être et le Néant, Sartre, qual um proustiano, parte "em busca do ser" perdido por Husserl, e perdido por torná-lo um irreal. Essa busca consumará a definitiva ruptura com o antigo mestre e a instalação necessária no terreno da ciência fundante.

VII

(A) Sartre fala dessa ruptura em Drôle de Guerre, quando trata da influência que Heidegger exerceu sobre ele. Segundo Sartre, para que essa influência ocorresse de fato foi preciso que, antes, ele tivesse "esgotado Husserl" (Sartre 7, p. 226) . Fala, por exemplo, de sua primeira leitura de Que É Metafísica? e de Ser e Tempo, em 1930 e 1934, respectivamente, e do fracasso que foram essas leituras; da última obra, por exemplo, não ultrapassou cinquienta páginas. Sentia então uma "repugnância" por essa "filosofia bárbara e tão pouco sábia após a genial síntese universitária de Husserl", para ele "mais acessível", dada a sua "aparência de cartesianismo".

Ao Sartre "husserliano", a filosofia de Heidegger parecia então "novamente caída na infância"; passaria quatro longos anos vendo "tudo através das perspectivas" de Husserl, até esgotá-lo: "Para mim, esgotar um filósofo é refletir em suas perspectivas, fazer idéias pessoais à sua custa até que eu caia em um beco-sem-saída" (id., ibidem) ${ }^{(22)}$. A última obra escrita sob a influência de Husserl é La Psyché; depois dela, diz Sartre, "pouco a pouco, sem que eu me desse conta, dificuldades se acumulavam, um fosso cada vez mais profundo me separou de Husserl": as dificuldades deveriam aqui conduzi-lo ao beco-sem-saída, apontado pelo próprio Sartre: "Sua filosofia evoluía no fundo para o idealismo, o que eu não podia admitir, e sobretudo, como todo idealismo ou como toda doutrina simpatizante, sua filosofia ti- nha sua matéria passiva, sua hylé, que uma forma vem modelar (categorias kantianas ou intencionalidade)" (Sartre 7, p. 226) ${ }^{(23)}$. Fis aqui o ponto-chave de ruptura com Husserl: a evolução de sua filosofia para o idealismo, consubstanciada no noema irreal. É nessa medida que na Introdução de L'Être et le Néant aparecerá o ataque à hylé, já que é a partir dela que se pode constituir o noema irreal, conforme interpretação de Sartre. Já não se tratará mais de apontar matérias dist intas para a percepção e a imagem mental, mas de recusar a própria noção de hylé passiva para a percepção.

(B) A busca do ser começa pela observação de que "o pensamento moderno realizou progresso considerável reduzindo o existente à série de aparições que o manifestam" (idem 10, p. 11) . Com isso, vêm abaixo todos os dualismos que turvavam a filosofia. Na verdade, nem todos os dualismos. Há ainda um outro, de que Husserl é vítima, e que estará na origem do erro husserliano, o noema irreal: o dualismo do finito e do infinito.

De início, o existente não se recuz a uma série finita de manifestações na medida mesma em que "cada uma delas é uma relação a um sujeito em perpétua mudança" (id., ibidem, p. 13). Além disso, se a série fosse finita, as primeiras aparições não teriam "a possibilidade de reaparecer" ou, pior ainda, elas poderiam ser "dadas todas ao mesmo tempo" (id., ibidem) . Dois absurdos que exigem a série infinita. A própria aparição, se "reduzida a si mesma sem recurso à série de que faz parte", nada seria senão "plenitude intuitiva e subjetiva". É assim que o objeto, se deve ser transcendente, e não plenitude subjetiva, exige que a aparição se faça "sempre transcender": 0 objeto mesmo "põe por princípio a série de suas aparições como infinitas" (id., ibidem) . Eis aí, segundo Sartre, o novo fenômeno husserliano. Aqui, a realidade da coisa é substituída pela objetividade do fenômeno, e essa objetividade é fundada por sua vez "em um recurso ao infinito" (id., ibidem) .

Ora, aonde isso nos levará? Sem dúvida, direto ao não-ser, ao noema irreal! Sartre aborda essa questão nas seçães IV e V da Introdução. De início, na seção IV, começa por recusar a tese husserliana de que esse é percipi, tese que em Husserl se efetiva na medida em que o ser mesmo do percipi aparece como constituído, é verdade que não por um sujeito "no sentido kantiano do termo", mas por uma subjetividade entendida como "imanência de si a si" 
(Sartre 10, p. 24) . Para mostrar que "o ser do percipi não pode se reduzir àquele do percipiens - isto é, à consciência" (id., ibidem), Sartre começa por "um exame das exigências ontológicas do "percipi'" (id., ibidem) .

Esse exame mostra de início que "o modo do percipi é o passivo" (id., ibidem, p. 25); Sartre fala aqui do modo; que se atente bem para isso, pois não se trata do ser do percipi, pois o que o exame deverá mostrar é que precisamente a passividade pode dizer respeito à maneira de ser, mas não ao ser (id., ibidem, p. 27) . "Sou passivo quando recebo uma modificação de que não sou a origem (...) Assim, meu ser suporta uma maneira de ser de que não é a fonte. Somente, para suportar, é ainda preciso que eu exista, e assim minha existência se situa sempre além da passividade" (id., ibidem, p. 25) . Se a passividade atingisse também o ser, já não haveria distinção entre criador e criatura: "Se o ser criado é sustentado até em suas mais ínfimas partes, se não tem nenhuma independência própria, (...) então a criatura não se distingue de nenhuma maneira de seu criador, ela se absorve nele" (id., ibidem) . Já não teríamos senão uma "falsa transcendência", um nada; a passividade é portanto "relação de um ser a um ser, e não de um ser a um nada" (id., ibidem, ).

Certamente, assegurar aqui a verdadeira transcendência (ou, se se quiser, a "transfenomenalidade") é mais um round na luta contra Husserl, pois, na interpretação de Sartre, a consciência husserliana pretende constituir, fundar o ser do percipi, justamente torná-lo passivo no seu ser mesmo. Isso, porém, não é tudo. É preciso lembrar ainda que, na medida em que "a passividade do paciente reclama uma passividade igual no agente", conforme o princípio de ação e reação (id., ibidem), nessa medida mesma Husserl será obrigadb a introduzir a passividade na noese, noutras palavras, a criar a hylé: ela representa a passividade do lado de cá, já que para constituir ser é também necessária a passividade no constituinte. Dessa vez, contudo, ao contrário do que ocorria em A Imaginação, a hylé aparecerá como "ininteligível". É verdade que só agora ela aparece ligada ao tema da constituição, e é sob esse prisma que ela aparece inaceitável: a hylé agora implica passividade e, portanto, opacidade. Dessa vez, pouco importa se ela não é "conteúdo de consciência", como A Imaginação lembrou diversas vezes: isso já não surte efeito. Agora, a hylé já não pode ser da consciência porque ela "se esvaneceria em translucidez e não poderia oferecer esta base impressional e resistente que deve ser ultrapassada para o objeto" (Sartre 10, p. 26) . Ser "híbrido", meio consciência, meio coisa, a hylé é uma ficção cujo sentido é permitir a constituição do ser, "a passagem de uma a outro" (id., ibidam) .

O mesmo exame se repete para a pretensão de que o ser do percipi seja relativo ao percipiens: "Que pode significar a relatividade de ser, para um existente, senão que este existente tem seu ser em outra coisa que nele mesmo, isto é, em um existente que ele não é?" (id., ibidem) . Mesmo concebido como irreal, é preciso que esse ser exista. Assim, a consciência não pode constituir, "fundar o ser transfenomenal do fenômeno" (id., ibidem, p. 27), e não pode precisamente porque ele é transfenomenal, isto é, transcendente.

Ora, mas como se dá a constituição em Husserl? Esse exame é importante porque ele nos mostra como surge a ficção do noema irreal. Para mostrá-1o, Sartre retoma o que dissera contra a passividade, o que significa agora que, "se se quer a todo preço que o ser do fenômeno dependa da consciência, é preciso que o dbjeto se distinga da consciência não por sua presença, mas por sua ausência, não por sua plenitude, mas por seu nada" (id., ibidem). Assim, se o objeto não é a consciência, é verdade contudo que ele não o é na medida em que "é um não-ser", não na medida em que é outro ser. Ora, precisamente assim aparece o noema husserliano, e a raiz disso, a fonte do erro de Husserl, reside na sua interpretação equívoca do "fenômeno": Husserl se mostrará vítima do dualismo finito/infinito mostrado acima.

(C) O dualismo se consagra em Husserl na medida em que, de início, o ser do objeto é por ele reduzido "à sucessão de suas maneiras de ser" (id., ibidem), razão pela qual Husserl é tido como "fenomenista" (id., ibidem, p. 115) : "Tendo reduzido, com razão, o dbjeto à série ligada de suas apariçães, eles (os fenomenistas) acreditaram ter reduzido seu ser à sucessão de suas maneiras de ser" (id., ibidem, p. 27) . Essa redução funda precisamente aquele "recurso ao infinito"; não é por outra razão que para Husserl as intenções que podem ser preenchidas num dado núcleo hilético não bastam para nos "fazer sair da subjetividade" (id., ibidem, p. 28) ; para além delas, são necessárias ainda as intençães vazias, as "verdadeiramente objetivantes", "aque- 
las que visam para além da aparição presente e subjetiva a totalidade infinita da série de aparições" (Sartre 10, p. 28; grifos nossos) .

Isso ocorre na medida em que essas intenções "não podem jamais ser dadas todas ao mesmo tempo", razão pela qual temos, de um lado, a "impossibilidade de princípio" de que os temos da série, em número infinito, existam de uma só vez "diante da consciência"; de outro lado, e simultaneamente, temos "a ausência real de todos esses termos, salvo um": essa impossibilidade e essa ausência de única exceção constituem-se justamente no "fundamento da objetividade" (id., ibidem). Aqui, a ausência das impressões correspondentes a essas aparições faz o ser abjetivo, pois, presentes, elas "desabariam no subjetivo": "Assim, o ser do objeto é um puro não-ser. Ele se define como uma falta. É o que se furta, o que, por princípio, não será jamais dado, o que se entrega por perfis fugitivos e sucessivos" (id., ibidem) . A realidade do objeto aparece aqui portanto inteiramente fundada na "plenitude subjetiva impressional" (esse é percipi), e a objetividade, por sua vez, fundada "no não-ser" (esse é irreal) .

É o fenômeno assim intenpretado a raiz do erro: nele, a pretensa redução do ser do objeto "à sucessão de suas maneiras de ser". Essa redução conduz direto ao não-ser exatamente porque ela força a buscar o ser no infinito! Mas, além disso, o próprio ser aparece como constituído, e aparece porque seu fundamento foi posto em suas aparições ("maneiras de ser") . Assim, a realidade, de um lado, se funda na noese, e a objetividade, por outro lado, se funda no infinito, objetividade posta para além do núcleo hilético dado, arrancada, por assim dizer, às intenções vazias, que justamente visam à série infinita. Realidade reduzida à noese e objetividade arrancada ao infinito são dois lados de uma mesma moeda que traduzem sempre uma má compreensão do fenômeno. Contra o ser constituído e integralmente passivo (portanto não verdadeiramente transcendente) que aparece, será necessário colocar o ser transcendente do percipi, ser transfenomenal, real e irredutível à aparição.

Transfenomenalidade já assegurada na seção II, onde se procurou mostrar que o "fenômeno de ser", a aparição de ser, desse ser "que pode ser fixado em conceitos" (id., ibidem, p. 16), exige um "ser dos fenômenos". A razão é simples: o que me aparece, o ser que se desvela a mim, não é da mesma natureza que o ser dos existentes que me aparecem. Posso ultrapassar $~$ fenômeno para a sua essência: trata-se aqui de "passagem do homogêneo ao homogêneo" (Sarte 10, p. 15), de onde a possibilidade de uma "recução eidética". Mas, se ultrapasso o existente para o fenômeno de ser, estarei de fato ultrapassando-o "para seu ser"? (id., ibidem) .

Ao falar que a "realidade humana" é ôntico-ontológica, "isto é, que ela pode sempre ultrapassar o fênomeno para seu ser" (id., ibidem), Heidegger teria alcançado o ser? Mas "o ser não é nem uma qualidade do objeto apreensível entre outras, nem um sentido do objeto" (id., ibidem) . Tudo o que se pode dizer é que o objeto é, não que ele possui o ser. Assim, o ser torna-se aqui "simplesmente a condição de todo desvelamento: ele é ser-para-desvelar e não ser desvelado" (id., ibidem), de onde a impossibilidade da redução fenomenológica. Daí por que ao pôr a questão do ser-mesa ou do ser-cadeira, Heidegger não ultrapassou o fenômeno para o seu ser: se "eu volto meus olhos da mesa-fenômeno para fixar o ser-fenômeno, que não é mais a condição de todo desvelamento - mas que é ele mesmo um desvelado, uma aparição", esse ser mesmo "tem por sua vez necessidade de um ser sobre o fundamento do qual ele possa se desvelar" (id., ibidem) . Parece que a crítica à concepção errônea do fenômeno vale não apenas para Husserl, mas também para Heidegger. E com efeito, ao expor a idéia de fenômeno, Sartre afima tratar-se da idéia "tal como se pode encontrá-la por exemplo na 'fenomenologia' de Husserl ou de Heidegger" (id., ibidem, p. 12) . Depois de ter dito isso, vem a crítica a essa idéia de fenômeno: ela contém o dualisno finito/infinito etc. A diferença estaria em Heidegger ter amitido o cogito e ter ido direto à analítica existencial (id., ibidam, p. 115) : ele não opera a redução fenomenológica, e com isso evita cair no noema irreal, mas nem por isso escaparia ao erro, que seria aqui julgar ter atingido o plano do ser, quando atingiu - é o que se pode atingir - o plano do fenômeno do ser, do sentido do ser (id., ibidem, p. 30). Assim, o fenômeno de ser aparece como "ontológico", no sentido "em que se chama ontológica a prova de Santo Anselmo e Descartes. Ele é um apelo de ser; ele exige, enquanto fenômeno, um fundamento que seja transfenomenal" (id., ibidem, p. 16) . 
(D) A "prova ontológica" será realizada na seção $\mathrm{V}$ e, evidentemente, por oposição ao ser constituído de Husserl; ela diz respeito ao ser transfenomenal, aquele irredutível à aparição, "à sucessão das maneiras de ser". E é por conta dessas duas concepções de ser que Sartre fala de duas concepções distintas de intencionalidade: "Ou entendemos que a consciência é constitutiva do ser de seu objeto, ou (...) que a consciência em sua natureza mais profunda é relação a um ser transcendente" (Sartre 10, p. 27) . Evidentemente, o primeiro sentido, por desconhecer a transfenomenalidade do ser, não se agüienta de pé: ele é a expressão do idealismo husserliano, e a intencionalidade toma-se aqui mera "caricatura" (id., ibidem, p. 153) .

Já o segundo sentido, aquele que assegura a transfenomenalidade, é o que respeita a transcendência como "estrutura constitutiva da consciência". Assim, se "cada aparição remete a outras aparições", é verdade também que "cada uma delas é já por si só um ser transcendente, não uma matéria impressional subjetiva - uma plenitude de ser, não uma falta - uma presença, não uma ausência" (id., ibidem, p. 28). A realidade não se funda aqui na noese, nem a objetividade é arrancada ao infinito, e pela razão simples de que se assegura a verdadeira transcendência. Sartre tem cuidado em afastar dessa prova ontológica a "refutação kantiana do idealismo problemático", pois não se trata de mostrar "a existência de fenômenos objetivos e espaciais", mas de mostrar "que a consciência implica em seu ser um ser não consciente e transfenomenal" (id., ibidam, p. 29) : eis o que mostra a verdadeira intencionalidade, eis a "prova ontológica". Daí por que a lembrança de Descartes, pois "estamos aqui no plano do ser, não no do conhecimento". E de fato: a prova ontológica reclama ser; e, tal como na $5^{2}$ Meditação a essência reclama existência, também aqui "a aparência reclama ser" (id., ibidkm) .

Vê-se pois que se encontra aqui reproduzido movimento análogo àquele estabelecido pela nova "regra cartesiana", segundo a qual o movimento deve ser do quid ao quod, da essência à existência (Guéroult 3, pp. 129-130) . É verdade, contudo, que esse movimento não diz respeito a Deus, de onde talvez se devesse pensar mais na $2^{a}$ e $6^{2}$ Meditações do que na 5í; entretanto, é a prova aplicada à essência de Deus que está aqui em questão, e para falar do "ser desta mesa, deste pacote de tabaco, da lâmpada, mais geral- mente (do) ser do mundo que é implicado pela consciência" (Sartre 10, p. 29). Eis o ser encontrado, que Husserl perdera; ele é transcendente, transfenomenal, não-passivo, irredutível "às maneiras de ser".

VIII

Todo esse movimento possibilita a Sartre retomar aquilo que, desde o início (já em 1934), the pareceu a vantagem maior da fenomenologia: a superação do impasse entre realismo e idealismo, a afimação da soberania da consciência e da transcendência absoluta do mundo. A intencionalidade era então o segredo maior; ela levou a pôr uma consciência vazia, "sem conteúdos": por ela, Sartre via o ocaso da representação. Que se lembre aqui do Essai ou do curto artigo onde Sartre aponta a intencionalidade como "idéia fundamental da fenomenologia de Husserl".

Ora, não é diferente o tema da Introdução de L'Être et le Néant. Novamente ressurge a querela entre idealismo e realismo. Dessa vez, entretanto, não se trata mais de enfrentar o representacionismo clássico, o que já foi feito nas obras anteriores, mas de enfrentar o idealismo husserliano. E novamente a intencionalidade aparece, já agora em um sentido que deve distinguir-se daquele presente em Husserl (por oposição a uma consciência constituinte, uma consciência que é relação a um ser transcendente) . E isso porque Husserl introduziu na consciência uma matéria, tornou-a cheia, matéria a partir da qual o próprio ser do mundo é constituído.

Assim, é possível afimar que sempre foi essa a perspectiva que Sartre desejou assegurar, apesar das mudanças no curso de sua leitura da fenomenologia. Se ele abandonou o terreno da psicologia para colocar-se no plano da filosofia primeira, não foi senão porque era necessário assegurar, desta vez, a transcendência absoluta do mundo contra o tardio idealismo husserliano. É certo que essa objeção traz consigo a posição da soberania da consciência, precisamente o outro ser que aparece na Introoução de $L^{\prime}$ Être et le Néant, meio pelo qual a querela é integralmente superada, e meio pelo 
qual é reafimada novamente a contingência absoluta de ambos os seres, do mundo e da consciência. Pois é esse tema que faz a unidade das diferentes leituras, dos diferentes momentos: foi a contingência que Husserl permitiu afimar no primeiro momento, e foi ela que ele pôs em risco, no segundo momento. Mas esse é tema para um próximo texto.

Astract: This paper examines Sartre's passage to the prima philosophia. The phenomenology greatest achievement - i.e. overcoming the argument between realism and idealism - will be endangered by Husserl's further thought which Sartre points out as an idealistic one. Refusing the concept of unreal noema, Sartre will retake the "true principles" of the phenomenology, starting again the speech of the prima philosophia.

Key-words: Sartre - psychology - phenomenology - conscience - intentionality - image - noema

\section{Notas}

(1) Certamente, ser-no-mundo é um conceito heideggeriano, ainda desconhecido por A Imaginação. Entretanto, referido em Esquisse, ele ainda exige que se vá até a "consciência transcendental e constitutiva", alcançável pela "redução fenomenológica" (Sartre 8, p. 13). Além do mais, a fenomenologia ainda aparece, seja a de Husserl, seja a de Heidegger, como a ciência fundante.

(2) Voltaremos a esse assunto mais adiante.

(3) Citado de Ideen, edição original alemã, p. 43.

(4) Citado de Ideen, edição original alemã, p. 226.

(5) Evidentemente, Sartre é vítima aqui da tradicional confusão entre irreal no sentido natural e irreal no sentido fenomenológico.

(6) Por exemplo, uma mancha em um muro: o saber, através dessa mancha, e ainda os movimentos, que se tornam simbólicos, criam a imagem. Mas a mancha não é posta como provida de propriedades representativas e portanto o objeto da imagem não é posto como existente. Se essa tese neutralizada é substituída "por uma tese positiva", se é conferida à mancha "um poder de representação", eis que estamos "em presença da imagem hipnagógica" (Sartre 13, pp. 78-9).

(7) Citado de Ideen, edição original alemã, p. 206.

(8) De que falaremos adiante.

(9) Ele já é citado no Essai. Cf. Sartre 9, p. 58.

(10) Quando Sartre, presumidamente, ainda não sofrera a "influência" de Heidegger!

(11) A primeira parte de L'Être et le Néant também contém uma regressão analítica e também a propósito de uma conduta que envolve o negativo.

(12) Trata-se da garantia de verdade. Sartre utiliza esse mesmo procedimento em L'Être et le Néant: após a regressão, a reflexão. 
(13) "(...) de que serve afirmar que o Nada funda a negação se é para fazer em seguida uma teoria do não-ser que separa, por hipótese, o Nada de toda negação concreta? Se eu emerjo no nada para além do mundo, como esse nada extramundano pode fundar esses pequenos lagos de não-ser que encontramos a cada instante no seio do ser? (...) É preciso verdadeiramente ultrapassar o mundo para o nada e voltar em seguida até o ser para fundar esses juízos cotidianos?" (Sartre 10, p. 55).

(14) Verdade posta pela interpretação de L'Être et le Néant, mas que, a nosso ver, era já a de L'Imaginaire, conforme dissemos acima.

(15) Certamente, o Nada absoluto criticado por Bergson, o da metafísica clássica, não é o de Heidegger: o Nada extra-mundano não é o "abismo original", não é anterior ao ser.

(16) Não há em Bergson, certamente, a totalidade, o avesso apenas do nada absoluto.

(17) Em L' Être et le Néant, diz Sartre: o Nada que "tira de si a força necessária para 'se nadificar'" (Sartre 10, p. 58).

(18) Afinal, o título da dora seguinte é l'être et le néant, não o oposto.

(19) Em L'Être et le Néant, Sartre denominou, respectivamente, negação externa e interna. Cf. Sartre 10, p. 223 e segs. Ver-se-á adiante que a negação interna é precisamente o que ele chama nadificação.

(20) Existencial aqui no sentido definido por Heidegger em Ser e Tempo: "Todas as explicitações que resultam da analítica do ser-aí são obtidas à luz de sua estrutura de existência. E é porque eles se determinam a partir da existencialidade que chamaremos existenciais os caracteres do ser-aí". Existenciais que, por sua vez, se opõem às categorias, que são "deteminações de ser (... ) características do ente que não é um ser-aí" (Heidegger 4, p. 159 e segs.) .

(21) Poder-se-ia indagar: para não ser tal ser não é necessário um conhecimento prévio desse ser? Só posso saber se não sou um japonês ou um inglês se tenho conhecimento prévio desses seres. Mas a negação de que falamos não é a distinção empírica; trata-se antes de uma "relação ontológica que deve tornar toda experiência possível e que visa a estabelecer como um objeto em geral pode exis- tir para a consciência" (Sartre 10, p. 224) . Não tenho experiência do objeto antes de constituí-lo como tal. Cf. idem, p. 224 e segs.

(22) Quatro anos que vão do Essai a La Psyché (ou Esquisse) . Exclui-se aqui a Conclusão de L'Imaginaire, escrita depois, e, muito provavelmente, a Introdução de Esquisse.

(23) Desanti se equivoca quando aponta, entre os três culs-de-sac que Sartre encontrou na fenomenologia de Husserl, o Ego, pois ele o recusou no momento em que ainda era (e permaneceu) "husserliano". Em seu lugar, precisaria falar da hylé. Cf. Desanti 2.

\section{Bibliografia}

1. Bergson, H. Deurres. Paris, PUF, 1959.

2. Desanti, J.-T. Sartre et Husserl ou Ies Trois Culs-de-Sac de la Phénoménologie Transcendantale. In: Ies Temps Modernes, no 531-533, Paris, 1990.

3. Guéroult, M. Descartes selon 1'Ordre des Raisons. Paris, AubierMontaigne, 1968.

4. Heidegger, M. Que É Metafísica? São Paulo, col. Os Pensadores, Abril cultural, 1973.

5. _. Etre et Temps. Paris, trad. Emmanuel Martineau, Authentica.

6. Prado Jr., B. Presença e Campo Transcendental - Consciência e Negatividade na Filosofia de Bergson. São Paulo, Edusp, 1989.

7. Sartre. Ies Carnets de la Drôle de Guerre. Paris, Gallimard, Paris, 1983. 


\begin{abstract}
8. _. Esquisse d'une Théorie des Émotions. Paris, Hermann, 1966.
9. _. Essai sur la Transcendance de l'Ego. Paris, J. Vrin, 1988.

10. _. L'Être et le Néant. Paris, Gallimard, 1969.

11. _ Une Idée Fondamentale de la Phénoménologie de Husserl: l'Intentionnalité. In: Situations I. Paris, Gallimard, 1947.

12. . A Imaginação. São Paulo, col. Os Pensadores, Nova Cultural, 1990.

13. - L'Imaginaire. Paris, Coll. Folio/Essais, Gallimard, 1986.
\end{abstract}

14. Spiegelberg, H. The Phenomenological Movement. Boston, Martinus Nijhoff, 1984. 